\title{
The Justiciability of Legislative Rules and the "Political" Political Question Doctrine
}

\author{
Michael B. Miller†
}

Legislative procedural rules, like statutes, constitutionally issue from the authority of Congress. Courts, however, usually accord special treatment to the procedural rules of the legislature. This Comment examines that judicial approach, exploring the justiciability of procedural rules. The author reviews the case law and discovers that courts' decisions to hear a case are not always consistent, but rather can depend on any number of factors. The author argues that the usual reasons advanced for special treatment of procedural rules are not convincing. Courts should not be paralyzed for fear of affecting the legislative process. Rather, courts should decline to interfere only when a participant in the legislative process brings a claim. Where an outsider comes to court with a claim based on a procedural rule, a court should not hesitate to reach the merits of the claim.

\section{INTRODUCTION}

The United States Constitution provides that each house of Congress shall "determine the Rules of its Proceedings." 1 Pursuant to this authority, Congress has devised a systein of procedural rules that governs the manner in which pieces of legislation are raised, investigated, considered, and decided. The entire legislative process is subject to this congressionally created system of rules.

Not surprisingly, people sometimes disagree over the content of these rules, or argue that a particular rule violates other constitutional provisions. Both legislators and private parties have resorted to the judicial process to resolve disputes over the proper application and interpretation of procedural rules. Sometimes the courts have agreed to resolve these disputes; at other times they have declined. Each time the question arises, however, the courts have stated their considered opimion that procedural rules are somehow special and merit different treatment from the general, run-of-the-mill statute.

This Comment considers the justiciability of legislative rules of procedure. Part I examines the nature of procedural rules in form and im

† A.B. 1987, Brown University; J.D. 1990, Boalt Hall School of Law, University of California, Berkeley.

1. U.S. CoNST, art. I, § 5, cl. 2. 
enforcement, stressing the political nature of these rules and their nonbinding quality within the legislature. Part II reviews the case law, concluding tliat eacli case presents umque clrallenges to a court deciding the justiciability of the claim. Sornetimes, the plaintiff challenges the constitutionality of a particular rule. At other times, the plaintiff asks the court to correct an allegedly erroneous interpretation of the procedural rule. At times a legislator is the plaintiff; at other times a private party. The court's decision to hear a case has depended, at different times, on eacli of these factors.

Part III argues that the reasons usually advanced for the special treatinent of procedural rules are unconvincing. This Part examines the impact of judicial review of procedural rules on the separation of powers and bicameralism. It concludes that while judicial review does affect the legislative process, this does not mean that the courts should play no role at all in the application of legislative rules. It merely counsels caution.

Finally, Part IV argues that the true reason for special treatinent of legislative rules of procedure should be the courts' fear of making the political process nonpolitical. Courts should hesitate to interfere with the inlierently political nature of legislative rules. Thus, when a legislator comes to court with a claim based on a procedural rule, the court slould exercise its traditional equitable powers to refuse relief. When a nonparticipant in tle legislative process bases a clain on a legislative rule of procedure, however, the court should reach the merits of the clain and provide a remedy where appropriate.

The political process may not be pretty, but it represents the way decisions are made in a dennocratic system. Judicial recoguition of the political nature of legislative rules slould limit the courts' interference in this political realm to cases where the interests of private parties are affected. This is the "political" political question doctrine.

\section{I}

How the Political Game Is Played: Congressional Rules of Procedure

In the beginning, congressional rules of procedure played a relatively minor role in the legislative process:

Courtesy, dignity and informality marked the proceedings of the Senate in the early days of the Republic. A body that on a chill morning might leave its seats to gather around the fireplace had no need for an elaborate system of procedure and rules. At the first session in 1789 the Senate adopted only 20 short rules, a number deened sufficient to control the 
proceedings of a Senate no larger than some modern-day congressional coinmittees. ${ }^{2}$

Today, the body of rules that govern the inanner in which legislation can be raised, considered, and decided has changed considerably, both in the sheer number of rules ${ }^{3}$ and in the importance of their application to the modern legislative process. This Section surveys the current landscape of legislative rules of procedure and the weight that Congress attaches to these rules as they arise in the day-to-day machinations of the legislative process.

\section{A. The Nature of Congressional Rules of Procedure}

The distinctive characteristic of congressional rules of procedure is that they are imposed on Congress by Congress itself. Article I, section 5 , clause 2 of the Constitution grants to each house of Congress the power to "determine the Rules of its Proceedings." 4 Even where procedural rules are imposed upon Congress by other provisions of article $\mathrm{I},{ }^{5}$ often Congress itself determines the ineaning and effect of those provisions. ${ }^{6}$ Each house is free to, and frequently does, interpret the requirements of article I differently. ${ }^{7}$ Thus, for the most part, Congress determines its rules of procedure free of any external pressures.

The most important exercise of the power vested in Congress by article I's rulemaking clause is adoption of the standing rules. The

2. CoNG. Q. INC., Congressional Quarterly's Guide to Congress 79 (3d ed. 1982).

3. See Senate Rules, contained in Senate Comm. on Rules and Administration, Senate Manual Containing the Standing Rules, Orders, Laws, and Resolutions AFFecting the Business of THE United STATEs Senate, S. Doc. No. 1, 98th Cong., 1st Sess. (1984) [hereinafter Senate Rules]; House Rules, contained in W. Brown, ConstrTution, Jefferson's Manual and the Rules of the House of Representatives, H.R. Doc. No. 279, 99th Cong., 2d Sess. (1987) [hereinafter House Rules].

4. U.S. CoNST. art. I, § 5, cl. 2.

5. E.g., id. cl. 1 ("a Majority of each [House] shall constitute a Quorum to do Business; but a smaller Number may adjourn from day to day"); id. at cl. 4 ("Neither House, during the Session of Congress, shall, without the Consent of the other, adjourn for more than three days, nor to any other Place than that in which the two Houses shall be sitting."); id. at cl. 3 ("[T] he Yeas and Nays of the Meinbers of either House on any question shall, at the Desire of one fifth of those Present, be entered on the Journal."); id. \& 7, c1. 2 ("[T]he Votes of both Houses shall be determined by Yeas and Nays, and the Names of the Persons voting for and against the Bill shall be entered on the Journal of each House respectively.").

6. See Bach, The Nature of Congressional Rules, 5 J.L. \& PoL. 725, 726-27 (1989).

7. See id. at 727-30 (the House and Senate interpret the quorum requirenent differently). The interpretations of the House and Senate differ froin each other in ways that reflect the character of each house:

The essential characteristic of the Senate's rules, and the characteristic that most clearly distinguishes its procedures from those of the House of Representatives, is their emphasis on the rights and prerogatives of individual Senators .... [T] he Senate's rules give greater weight to the value of full and free deliberation than they give to the value of expeditious decisions....

S. Bach, AN Introduction to the Legislative Process on the House Floor 1-2 (Congressional Research Service Rep. No. 176, 1987). 
standing rules, adopted by each house independently, establish the basic structure within which legislative decisionmaking takes place. ${ }^{8}$ Alongside these rules exists a large body of precedent consisting of the prior procedural rulings of each house. ${ }^{9}$ The rules embodied in precedent often carry as much persuasive force as the standing rules themselves, ${ }^{10}$ and in soine instances are even more authoritative than directly contrary standing rules. ${ }^{11}$

Finally, conventional practices delineate the proper conduct of legislative procedure. ${ }^{12}$ Although it is difficult to distmguish between precedent and practice, practices generally consist of those customs "to which adherence is expected and routime." 13 Akin to these conventional practices are those "conventions of legislative practice which normally are followed, but which may be violated when circumstances warrant."14 These last two types of procedural guidelines probably cannot be enforced by Congress as rules, but they do have considerable normative power. ${ }^{15}$

8. See Senate Rules, supra note 3; House Rules, supra note 3. The standing rules of each house include not only those rules adopted as part of the House and Senate Rules, but also rules adopted as part of statutory provisions. See, e.g., Congressional Budget and Impoundment Control Act of 1974, Pub. L. No. 93-344, $\S \S 901-906,88$ Stat. 297, 330-32 (1974); War Powers Resolution, Pub. L. No. 93-148, §§ 5-7, 87 Stat. 555, 556-58 (1973); Legislative Reorganization Act of 1970, Pub. L. No. 91-510, 84 Stat. 1140 (1970); Legislative Reorganization Act of 1946, Pub. L. No. 79. 601, ch. 753, 60 Stat. 812 (1946); Balanced Budget and Emergency Deficit Control Act of 1985, Pub. L. No. 99-177, § 271, 99 Stat. 1037, 1094 (1985); Consolidated Ommibus Budget Reconciliation Act of 1986, Pub. L. No. 99-509, § 7006, 100 Stat. 1874, 1949-50 (1986).

9. Precedents are collected in C. Cannon, Cannon's Precedents op the House op Representatives (1935); L. Deschler, Deschler's Precedents of the United States House of Representatives (1977); A. Hinds, Hinds' PRECEDENTS Op the House of Representatives (1907); F. Riddick, Senate Procedure Precedents and Practices, S. Doc. No. 2, 97th. Cong., 1st Sess. (1981). See infra text accompanying notes 17-26 (discussing how the House and Senate rule on procedural matters).

10. Bach, supra note 6, at 733. See also L. DESCHLER, supra note 9, at vii ("precedents may be viewed as the 'common law,' ... with much the same force and binding effect").

11. Bach, supra note 6 , at 733. Not all precedents, however, have equal force. For cxample, precedents created when the Senate itself votes on a procedural issue carry more weight than merc rulings of the Chair. Id. at 734 . Furthermore, the political exigencies surrounding a procedural ruling may affect the persuasiveness of the precedent. Id. at 756.

12. Id. at 734 .

13. Id.

14. Id. at 735.

15. The normative power of these and other types of informal procedural guidelines should not be underestimated:

Congress is regulated not only by formal rules, but by informal ones that influence legislative procedure and member behavior. ...

Folkways ... are unwritten norms of behavior that members are expected to observe. ... Several of the more important are "legislative work" (members should concentrate on congressional duties and not be publicity seekers), "courtesy" (members should be solicitous toward their colleagues and avoid personal attacks on them), and "specialization" (members should master a few policy areas and not try to impress their colleagues as a "jack of all trades"). 


\section{B. The Flexibility of Rules of Procedure}

The complex system of rules regulating Congress often does not actually constrain legislative behavior. In fact, legislative rules in whatever form are often most easily recognized as those provisions that Congress waives, ignores, or reads out of existence when considering a piece of legislation. This creative apphication of the rules cannot be credited to sheer caprice. Instead, it amounts to a conscious effort by both houses of Congress to preserve a degree of flexibility in the legislative process. ${ }^{16}$ Congress has several weapons at its disposal to achieve this end.

One way in which Congress provides for flexibility is by using entirely different sets of rules in different modes of the legislative process. The Senate, for example, has two sets of procedural guidelines. One applies when the Senate operates under its normal rules, while the other applies only where cloture has been invoked. ${ }^{17}$ For its part, the House operates under any of five different sets of rules. ${ }^{18}$ Each mode presents different options to the House, and a bill that fails to pass procedural muster in one mode is not necessarily excluded from consideration by the others. ${ }^{19}$

Both houses also have the option of setting aside particular rules, or creating entirely new ones, by unanimous consent. ${ }^{20}$ This device is especially popular in the Senate, where standing rules and precedents exist to control the practice. ${ }^{21}$ Of course, even those rules can always be set aside by unanimous consent.

W. Oleszek, Congressional Procedures and the Policy Process 11 (3d ed. 1989).

Of course, not every Senator has felt bound by these informal rules. For example, one Senator earned a degree of fame for

his continual violation of the rules, customs, and procedures nnder which the Senate operates .... [T] forth ... provide the framework for the resolution of charged political issues .... The observance of Senate folkways requires patience, restramt, and moderation, however; these were qualities which the junior senator from Wisconsin singularly lacked. Instead, he brought to the Upper Chamber a restless and compulsive energy, a hunger for power and public notice, and a casual disregard for custom and authority.

The "junior senator from Wisconsin" was Joseph McCarthy. R. GRIFFITH, The Politics of FeaR: Joseph R. MCCARTHY AND THE SENATE 13-14 (2d ed. 1987).

16. Bach, supra note 6, at 736; see also S. BACH, supra note 7, at 1-2 ("Underlying most of the rules that Representatives may invoke, and procedures the House may follow, is a fundamentally important premise-that a majority of members ultimately should be able to work their will on the floor.").

17. Senate Rules, supra note 3 , at 20-22 (Rule XXII).

18. See Bach, supra note 6 , at 736-37 (the form of legislative decisionmaking in the House varies depending upon whether it operates by call of the Consent Calendar, under suspension of the rules, in the House, in Committee of the Whole, or in the Honse as in the Committee of the Whole).

19. Id. at 737 .

20. Id. at 737-38.

21. See, eg., Senate Rules, supra note 3 , at 5 (Rule V, ff 1). 
But by far the most important factor ensuring flexibility in the procedural rules is the simple fact that Congress itself enforces its own system of rules. One observer has noted that "[i]t is usually the responsibility of each Representative to protect his or her own interests by identifying proposed actions that would violate the rules and by making appropriate poimts of order at the proper times."22 A rule is not binding if it is not invoked; the rules have absolutely no effect unless a nember brings them into play. ${ }^{23}$

Finally, in both houses, the ruling of the Chair on a point of order can be overturned by a majority vote of the membership. ${ }^{24}$ Although rulings of the Chair in the House are "rarely appealed and are never overruled in contemporary practice," 25 the Senate may not only overrule the Chair, but in certain instances may vote on a point of order before the Chair rules on it. ${ }^{26}$ Thus, particnlarly in the Senate, the rules are not permitted to stand in the way of Congress' policy objectives.

Not surprisingly, votes on procedure often amount to votes on policy. It is one thing to say that a certam motion or amendment is not in order on the Senate floor; it is quite another to say that the Senate will not consider it anyway. ${ }^{27}$ Indeed, the strategic manipulation of rules by crafty legislators may ensure the passage of bills that imght otherwise fail. 28

The Natural Gas Policy Act of $1978^{29}$ provides a sinple example of how procedural rules can be used to further policy objectives. President Carter's imitial proposal to partially deregulate interstate natural gas prices ran into problems in both the House and Senate and was ultimately replaced by shightly different compromise bills. To ensure passage of the compromise package, the House Rules Committee proposed a closed rule that tied the natural gas bill to the entire energy bill: one could vote for both or for neither. The House adopted the closed rule by one vote, and ultimately enacted the compromise package. It is unlikely that the bill would have survived without the House Coinmittee's manipulation of the procedural rules. ${ }^{30}$

22. Bach, supra note 6 , at 739 .

23. Id. at $739-40$.

24. House Rules, supra note 3, at 311-13 (Rule I, cl. 4); Senate Rules, supra note 3, at 19-20 (Rule XX, ๆ 1).

25. Bach, supra note 6 , at 740 (citation omitted).

26. Id. at $740-41$.

27. Id. at 741 .

28. There are limits on such manipulation, however. Members may hesitate to usc a particular procedural trick for fear that use of the trick will become commonplace. The fear is that creative use of procedure will, quite literally, "set a precedent."

29. 15 U.S.C. $\$ 3301$ (1988).

30. Representative Young (R-Alaska) admitted:

I think that there is no question but that the vote on this rulc is a vote for or against the gas 


\section{The View Outside of Congress: Legislative Rules That Look Like Statutes}

The preceding two Sections provided a description of legislative rules from the point of view of members of Congress. To thein, legislative rules must seem wondrous creatures, phable and complex. Froin Congress' perspective, legislative rules affect only the way that decisions about third parties are made, without affecting those third parties directly. There appears little reason, then, for the judiciary to get involved. After all, only the duties and obhigations of the members of one coordinate branch in relation to one another are imphicated. In this sense, procedural rules are quite different froin statutes, which project their force outside the walls of Congress.

This conception of procedural rules and statutes as ideal types has soine truth, but it also misleads. Although procedural rules generally do serve arcane purposes-having little effect on the interests of third parties-in some cases they do affect third parties. For exainple, a procedural rule may grant an individual certain rights with respect to Congress. ${ }^{31}$ If Congress should subsequently violate those rights, that individual's interest clearly has been affected as directly as if Congress had enacted a statute. At other times, Congress might enact a bill pursuant to unconstitutional procedures. ${ }^{32}$ An individual who would have had standing to challenge the unconstitutional rule were it embodied in a statute has the same injury when the unconstitutional provision is contained in a procedural rule. The form of the action in question should not determine the outcome of a determination of justiciabihty. Instead, the effect of that action should be decisive.

This Comment assumes that there is a difference between statutes and procedural rules, and that this difference affects the justiciability of claims based on violations of procedural rules. However, any attempt to distinguish between these types of rules by closely scrutinizing the differing forms of statutes and rules inevitably results in disappointinent. The difference can be found only by looking at the interests invoked when a

pricing compromise. Left in a total energy package, the compromise stands a good chance of passage with the other provisions. But I fear that if the gas compromise is taken out and voted on separately, its chances of enactment will diminish.

W. Eskridge \& P. Frickey, Cases and Materials on Legislation: Statutes and the CreATION OF PUBlic Policy 373 (1988).

31. See Yelhin v. United States, 374 U.S. 109 (1963) (procedural rule granted witness testifying during a Committee investigation the right to have injury to reputation considered in proceeding to decide whether public interrogation is appropriate). Yellin is discussed at infra text acconupanying notes 65-73.

32. See United States v. Ballim, 144 U.S. 1, 1 (1892) (plaintiff alleged that the constitutionally mandated quorum was not present when statute was approved). Ballin is discussed at infra text accompanying notes $38-45$. 
legislative rule is challenged. Unfortunately, the courts have not always found themselves up to this task.

II

Legislative Rules AND Resort TO THE JUdicial PROCESS

\section{A. The Supreme Court's Approach: Traditional Doctrine and the Court's Departures From It}

Legislative rules of procedure may not be rigorously enforced in Congress, but this does not prevent people from sumg over them. Plaintiffs may challenge the constitutionality of a rule, ${ }^{33}$ or ask a court to correct an erroneous interpretation of it. ${ }^{34}$ Sometimes a member of Congress brings the suit; ${ }^{35}$ at other times an individual challenges the congressional action. ${ }^{36}$ Whatever the particular facts of the challenge, any suit involving the propriety of congressionally created rules of procedure or Congress' interpretation of the rules raises separation of powers concerns not present in the ordinary lawsuit. ${ }^{37}$

The courts have not taken a principled approach to these cases. Instead, they have felt their way through each case, determining the justiciability of procedural rules by examining the identity of the parties and the underlying inerit of the claim. The only consistency in these cases is that the courts always begin their analyses with the proposition that article I, section 5, clause 2 of the Constitution represents a textual commitment to Congress to interpret legislative rules of procedure.

United States v. Ballin ${ }^{38}$ provided the Supreme Court with its first

33. See, e.g., Ballin, 144 U.S. at 5-6 (plaintiff challenged the constitutionahty of quorum rule); Vander Jagt v. O'Neill, 699 F.2d 1166 (D.C. Cir. 1983) (Republican plaintiff challenged the constitutionality of the Democratic House's method of distributing committee seats).

34. See, e.g., Yellin, 374 U.S. 109 (petitioner challenged House's application of rule goveruing when a witness will be interrogated in executive session); Christoffel v. United States, 338 U.S. 84 (1948) (petitioner challenged House's interpretation of its quorum rule); United States v. Smith, 286 U.S. 6 (1932) (Smith challenged Senate's interpretation of its rule governing reconsideration of Senate vote).

35. See, e.g., Smith, 286 U.S. at 26 (suit brought by U.S. Attorney upon request of the Senate); Gregg v. Barrett, 771 F.2d 539 (D.C. Cir. 1985) (plaintiffs included three members of Congress); Vander Jagt, 699 F.2d 1166 (plaintiffs were 14 Republican party members of Congress).

36. See, e.g., Yellin, 374 U.S. 109 (defendant raised issue as an affirmative defense); Christoffel, 338 U.S. 84 (petitioner successfully raised affirmative defense that quornm rule should be interpreted differently for crime of perjury and for legislative business); Gregg, 771 F.2d 539 (plaintiffs included private parties).

37. For the typical formulation of this concern, see Metzenbaum v. Federal Energy Regulatory Commission, 675 F.2d 1282, 1287 (D.C. Cir. 1982) ("To decide [to review legislative rules] would subject Congressional enactments to the threat of judicial invalidation on each occasion of dispute over the content or effect of a House or Senate rule."). The separation of powers issue is generally overstated. See infra text accoinpanying notes 103-13.

38. 144 U.S. 1 (1892). 
opportunity to address the justiciability of procedural rules. In Ballin, defendants asked the Court to declare a customs usties act passed in accord with House Rule XV invalid. Rule XV provided that "the nanies of meinbers sufficient to inake a quorum in the hall of the house who do not vote shall be ... counted and aunounced in determining the presence of a quorum to do business." 39 Defendants contended that the constitutional requirement of a "Quorum to do Business"40 demanded that, contrary to the provision of Rule XV, only those ineinbers actually voting should be included in the quorum. ${ }^{41}$ Defendants argued that the act never received the approval of a Congress able to approve it, and therefore it could not be enforced as law.

Oddly, the Court, rather than accepting Congress' interpretation of the quorum requirement, expressly stated that the Constitution "prescribed no inethod of inaking this determination," 42 and that Congress acting on its own could prescribe any reasonable method it desired. ${ }^{43}$ That is, instead of inerely vahidating Congress' determination as constitutionally acceptable, the Court ceded altogether the power to interpret this provision of the Constitution. Justice Brewer wrote, "[N]either do the advantages or disadvantages, the wisdoin or folly, of such a rule present any inatters for judicial consideration. With the courts the question is ouly one of power. The Constitution empowers each house to deterinine its rules of proceedings." 44 Thus, the Court's holding obscured the boundary between a legislative rule adopted pursuant to article I, section 5 , clause 2 , and those legislative rules actually provided for in the text of the Constitution.

Contrary to the Court's apparent intentions, its holding in Ballin did theoretically place some limits on Congress' rulenaking powers. Most importantly, the Court provided the standard by which future legislative rules would (or would not) be judged:

[Congress] may not by its rules ignore constitutional restraints or violate fundamental rights, and there should be a reasonable relation between the mode or method of proceeding established by the rule and the result which is sought to be attained. But within these limitations all matters of method are open to the determination of the house ....45

In essence, the Court, while reserving the right to review congressional

39. Id. at 5 (quoting House Journal 230, Feb. 14, 1890).

40. U.S. CONST. art. I, §5, cl. 1 .

41. This was considered the general rule before Congress adopted Rule XV in 1890. See THE CONSTITUTION OF THE United States of America: ANALYSIS AND INTERPRETation, S. DoC. No. 16, 99th Cong., 1st Sess. 119-20 (1987).

42. Ballin, 144 U.S. at 6.

43. Id.

44. Id. at 5 .

45. Id. 
rules for constitutionality, left most of the field to the discretion of the legislative branch.

The Supreme Court adopted a more intrusive position in United States v. Smith.$^{46}$ In Smith, the Senate sent to President Hoover a confirmation resolution of one of his appointments to the Federal Power Coinmission. ${ }^{47}$ Relying on Senate Rule XXXVIII, the Senate later asked President Hoover to return the resolution for reconsideration. ${ }^{48}$ When the President refused, the Senate reconsidered the noinination anyway and subsequently rejected it. ${ }^{49}$

The dispute in Smith concerned the meaning of Rule XXXVIII. ${ }^{50}$ The Senate claimed that any notification of approval sent to the President remained subject to the provision in the Senate Rule that allowed for reconsideration of confirmation votes. The executive branch took the position that, once approval was communicated to the President, the Senate could request that the President return the nomination for reconsideration, but the President was not obliged to do so.

The factual setting in Smith clearly brought the Court outside the confines of Ballin. In Ballin, the Court suggested that legislative rules were justiciable to the extent that they (1) did not coinply with "constitutional restraints"; (2) violated fundamental rights; and (3) bore no "reasonable relationship" to "the result which is sought to be attained."51 Smith, in contrast, involved a simple case of rule interpretation. A strict reading of Ballin would prevent such an inquiry. ${ }^{52}$

Nevertheless, the Court chose to decide the issue presented in Smith. The Court recognized that "to place upon the standing rules of the Senate a construction different from that adopted by the Senate itself when the present case was under debate is a serious and delicate exercise of judicial power." ${ }^{\text {s3 }}$ At the same time, the Court recognized a stronger

46. 286 U.S. 6 (1932).

47. Id. at 27.

48. Id. at 28 .

49. Id. at 29.

50. Rule XXXVIII provided in pertinent part:

When a nomination is confirmed or rejected, any Senator voting in the majority may move for a reconsideration on the sane day on which the vote was taken, or on either of the next two days of actual executive session of the Senate; but if a notification of the confirmation or rejection of a nomination shall have been sent to the President before the expiration of the time within which a motion to reconsider may be made, the inotion to reconsider shall be accompanied by a motion to request the President to return such notification to the Senate.

Id. at 30-31.

51. Ballin, 144 U.S. at 5.

52. The Court in Ballin began its inquiry by noting that "[t]he action taken was in direct compliance with that rule." Id. This could be rcad to imply that the Court had authority to interpret legislative rules and enforce them in judicial procecdings. It is doubtful, howcver, that the Ballin Court intended such a broad reading.

53. Smith, 286 U.S. at 48. 
principle: when "the construction to be given to the rules affects persons other than members of the Senate, the question presented is of necessity a judicial one." 54 Thus, when the dispute involved more than merely intralegislative squabbling, the Court readily assumed a more intrusive role.

While the Smith Court claimed to "give great weight to the Senate's present construction of its own rules," would any case involving a problem of interpretation. Relying on the language of the relevant standing rules, the history of their treatment in the Senate, and Senate precedent, the Court concluded that the President was not compelled to return the nomination. ${ }^{56}$ The Senate, according to the Court, interpreted its own rules incorrectly.

Christoffel v. United States ${ }^{57}$ provides another example of the Supreme Court's willinguess to take an active role when procedural rules affect people outside of Congress. Christoffel appeared as a witness before the House Committee on Education and Labor. On the basis of his testimony there, he was later convicted of perjury. ${ }^{58}$ Christoffel claimed that, imsofar as the statute required "'an oath or affirmation before a competent tribunal," "59 the conviction could not stand because at the time of the alleged perjury, a quorum of the Committee was not present. Christoffel argued that the lack of a quorum deprived the Committee of its status as a "competent tribunal." ${ }^{10} \mathrm{He}$ further asserted that it was irrelevant that a quorum was present when testimony beganthree hours before the perjurious stateinents were actually made. ${ }^{61}$

The Supreme Court reversed the conviction. Since the presence of a quorum constituted an element of the crime, no conviction could be sustaimed without it. The Court acknowledged that, as a matter of legislative procedure, where no point of order is raised, a quorum is presumed to continue. ${ }^{62}$ But Christoffel, as a nonmember, obviously had no capacity to raise a point of order. As the Court stated, "In a criminal case affectimg the rights of one not a member, the occasion of trial is an appropriate one for petitioner to raise the question." 63

As in Smith, the Christoffel Court interpreted the procedural rule accordimg to general principles of statutory construction. The dissent saw this as fundamentally inconsistent with the principles earlier

54. Id. at 33 .

55. Id.

56. Id. at 35-49 (tracing previous applications of the rule and concluding that it has never been read to bind the executive).

57. 338 U.S. 84 (1948)

58. Id. at 85 .

59. Id. at 85 n.2 (quoting D.C. CODE. ANN. § 22-2501 (1989) (emphasis added)).

60. Id. at $85-86$.

61. Id. at 86 .

62. Id. at 88 .

63. Id. 
expressed in Ballin. Justice Jackson's dissenting opinion argued that the legislative practice of Congress, even in the absence of a written rule, could constitute an exercise of the rulemaking power and thus be beyond the Court's authority to adjudicate:

There is no requirement, constitutional or otherwise, that [Congress'] body of parhamentary law must be recorded in order to be authoritative.... This Court accordingly can neither determine the rules for either House of Congress nor require those rules to be expressed with any degree of explicitness other than that chosen by the respective Houses. . . .

... The House had adopted the rule and practice that a quorum once estabhislied is presumed to continue unless and until a point of no quorum is raised. By this decision, the Court, in effect, imvalidates that rule despite the limitations consistently imposed upon courts where such an issue is tendered. ${ }^{64}$

The dissent apparently attached no importance to the effect of the "unwritten rule" involved here on individuals who were not members of Congress. Justice Jackson saw the rule as retaiming its binding force-if Congress wished it to-in any event.

Yellin v. United States ${ }^{65}$ also imvolved the effect of a procedural rule on the interests of a private party. Petitioner Yellin refused to answer questions put to him by a Subcommittee of the House Committee on UnAmerican Activities. Yellin's refusal to answer led to his conviction on four counts of contempt of Congress. ${ }^{66}$

Yellin contended that the Cominittee failed to comply with its own rules and thus his conviction could not be sustained. The rule at issue was Committee Rule IV, which required the Committee to consider injury to the witness' reputation when deciding whether to hold the interrogatory session in a public or an executive session. ${ }^{67}$ Yellin's claim centered on the fact that the Coinmittee apparently failed to consider reputational injury in response to his request for an executive session. ${ }^{68}$

64. Id. at 91, 95 (Jackson, J., dissenting) (citations omitted).

65. 374 U.S. 109 (1963).

66. Id. at 111 .

67. Id. at $114-15$.

68. Yellin had sent a telegram to the Committee requesting that they consider the possible injury to his reputation resulting from examining him in public. At trial, Congressman Walter, the Chairman of the Committee, testified rather confusedly concerning this request:

Q: [By Mr. RABINowITz [Yellin's counsel]] So that at the time I raised at this hearing the question of the telegrams, you didn't know anything about any telegrams, and you weren't sufficiently interested to find out what I was talking about; is that right?

A: [By Congressman WALTER] Well, not exactly that, Mr. Rabinowitz. I was interested in knowing. I knew that you made an application for an executive session.

Q: How did you know that?

A: Well, the telegram; at least, that's what you started to talk about.

Q: You knew it at the time of the hearing? 
The Court reversed the conviction. It paid homage to the notion that it should give weight to Congress' own interpretation of its rules, but noted that where Congress clearly intended the rule as a protective measure for the benefit of witnesses, "the inost logical person to have the right to enforce those protections is the witness himself." 69 Of course, the Court could not guarantee that even if the Committee had considered the reputational concern, the interrogatory session would have proceeded in executive session. ${ }^{70}$ Nonetheless, Yellin was "at least entitled to have the Coinmittee follow its rules and give him consideration according to the standards it ha[d] adopted in Rule IV."71

The majority opinion in Yellin, like the one in Christoffel, was accompanied by a dissenting opmion that took the majority to task for allegedly overstepping its jurisdictional bounds. Justice White's dissent stressed that Yellin involved a question of rule interpretation rather than constitutionality. ${ }^{72}$ According to the dissent, this distinction justified a inore deferential scope of review: "While the testimony is reasonably clear as to the Coinmittee's construction and application of its own rule, if there were any doubt about the inatter it is not our place to resolve every doubt against the Committee."73

\section{B. The Lower Federal Courts' Approach}

Lower federal courts have also addressed the justiciability of legislative rules. Like the Supreme Court, these courts have often focused their inquiry on the status of the plaintiff. For example, in Vander Jagt $v$. $O^{\prime} N e i l l,{ }^{74}$ a group of House Republicans challenged on fifth annendment grounds their party's disproportionately small representation on various House standing committees. ${ }^{75}$ The trial court dismissed the coinplaint, finding that the textual commitment in article I, section 5 , clause 2

A: No. Isn't that what you started to talk about?

Q: When did you first learn that I had made an application for an executive session?

A: I believe today. I never had seen these telegrams, actually. I heard you mention them, at least now my recolleetion is that I heard you mention them, but I haven't seen them until this minute.

Id. at $113 \mathrm{n} .3$ (Court's emphasis omitted).

69. Id. at 116 .

70. Id. at 118 .

71. Id. at 121; see also United States ex rel. Accardi v. Shaughnessy, 347 U.S. 260, 268 (1954) (presenting same issue in the context of administrative law).

72. Yellin, 374 U.S. at 124 (White, J., dissenting).

73. Id. at 146.

74. 524 F. Supp. 519 (D.D.C. 1981), aff'd 699 F.2d 1166 (D.C. Cir.), cert. denied, 464 U.S. 823 (1983).

75. Id. at 1167 . The circuit court noted that "[e]ven though Republicans constituted $44.14 \%$ of the House and Democrats $55.86 \%$, Republicans were given only $40 \%$ of the seats on the Budget Committee and the Appropriations Committee, only $34.29 \%$ of the Ways and Mcans Committec seats, and only $31.25 \%$ of the Rules Committee seats." Id. The Republicans claimed that this 
ousted jurisdiction. ${ }^{76}$

The District of Columbia Court of Appeals affirmed, but on different grounds. ${ }^{77}$ Referring to article I's grant of rulemaking authority, the court opined:

[T]his authorization of power to Congress is not analytically different from many other constitutionally enumerated powers. So it is not evident why we must treat congressional rules with "special care," or with more than the customary deference we show other legislative enactments. ${ }^{78}$

The court cited Professor Louis Henkin in support of this proposition:

"Judging from the cases, even the 'textually demonstrable commitment' of an issue to the pohtical branches apparently does not necessarily mean exclusive and final commitment to the pohtical branches without judicial review, but only the kind of commitment found, say, in the grants to Congress in Article I, $\S 8$; the courts consider daily whether the political branches exercise power textually committed to them with due respect for constitutional limitations or prohibitions."79

The court thus held that the rulemaking clause does not except legislative rules from judicial review altogether. Rather, it "simply ineans that neither [the Court] nor the Executive Branch may tell Congress what rules it must adopt." 80

Nonetheless, the court, relying on its "discretion . . . to grant or withhold injunctive or declaratory rehief,"81 refused to intercede on behalf of the plaintiffs. The court noted the " 'startlingly unattractive' idea, given [its] respect for a coequal branch of government, for [it] 'to tell the Speaker of the ... House of Representatives how many Democrats ... he is to appoint to the standing cominittees." "82 But the fact remains that the court recognized its power to do so had it thought better of it.

distribution violated their equal protection and due process rights. Id. The committees in question are generally considered among the most important in Congress.

A similar claim was rejected in Davids v. Akers, 549 F.2d 120 (9th Cir. 1977), a case concerning chagrined Democrats in the Arizona state legislature.

76. Vander Jagt, 524 F. Supp. at 521. The trial court also relied on the speech and debate clause in its analysis. Id.

77. Vander Jagt, 699 F.2d at 1167.

78. Id. at 1173 .

79. Id. at 1173 n.17 (quoting Henkin, Is There a "Political Question" Doctrine?, 85 YALE L.J. 597,605 u.27 (1976) (citations omitted)).

80. Id. at 1173. The court continued, stating that "Article I does not alter our judicial responsibility to say what rules Congress may not adopt because of constitutional infirmity." Id. (emphasis added).

81. Id. at 1174 (quoting McGowan, Congressmen in Court: The New Plaintiffs, 15 GA. L. REV. 241, 262 (1981)). Judge McGowan's solution was also adopted in Riegle v. Federal Open Market Cominittee, 656 F.2d 873 (D.C. Cir.), cert. denied, 454 U.S. 1082 (1981).

82. Vander Jagt, 699 F.2d at 1176 (quoting Davids v. Akers, 549 F.2d 120, 123 (9th Cir. 1977)). 
What might have convinced the Vander Jagt court to think better of it? The answer might be found in Gregg v. Barrett. ${ }^{83}$ Gregg involved both congressional and private-party plaintiffs' claims of a violation of their first amendinent rights. Plaintiffs contended that Congress had reneged on its commitinent to publish an accurate record of its proceedings, thereby violating the congressional plaintiffs' first ainendinent right to transmit, and the private plaintiffs' right to receive, an accurate report. ${ }^{84}$ The trial court held that the speech and debate clause precluded judicial cognizance of the issues, and dismissed the suit. ${ }^{85}$ The Court of Appeals affirmed, but on different grounds.

Gregg's miportance lies in the court's distinction between plaintiffs according to their status as individuals or legislators. ${ }^{86}$ The court rehed on the saine discretionary powers as in Vander Jagt in dismissing the suit as to the congressional plaintiffs. ${ }^{87}$ This discretionary doctrine allows the court to dismiss suits brought by congressional plaintiffs "[w]here a congressional plaintiff could obtain substantial rehef from his fellow legislators through the enactinent, repeal, or ainendinent of a statute."88

Of course, the saine considerations did not apply to the privateparty plaintiffs. In fact, "an important reason to withhold equitable relief for congressional plaintiffs is the possibility that other, private plaintiffs may bring suit in a context less laden witlı separation-of-powers concerns." ${ }^{89}$ The court ultimately dismissed this lialf of the suit for failure to state a cause of action, ${ }^{90}$ but it did in fact reach the inerits.

Gregg involved the consideration of a statute ratler than a procedural rule, ${ }^{91}$ but there is no reason to conclude that its distinction between suits brought by legislators and those brought by individuals should not also apply to cases involving legislative rules. While the court

83. 771 F.2d 539 (D.C. Cir. 1985).

84. Id. at 540-41. Congress' authority over the Congressional Record stems from 44 U.S.C. $\S 901$ (1988) ("The Joint Committee on Printing shall control the arrangement and style of the Congressional Record, and while providing that it shall be substantially a verbatim report of proceedings, shall take all needed action for the reduction of unnecessary bulk."). The source of the renewed interest in this nearly forgotten act of yesteryear was Miller, Congress's License to Lie, READER'S DIGEST, Feb. 1983, at 72.

85. Gregg, $771 \mathrm{~F} .2 \mathrm{~d}$ at 540 .

86. Id. at $543-46$.

87. Id. at 546 .

88. Riegle v. Federal Open Mkt. Comm., 656 F.2d 873, 881 (D.C. Cir.), cert. denied, 454 U.S. 1082 (1981).

89. Gregg, 771 F.2d at 546.

90. Id.

91. The constitutional claim forwarded in Gregg was something of a non sequitur. Why should the Act of 1895 declaring Congress' commitment to the publication of an accurate record vest plaintiffs with a first amendment right? A potentially more convincing claim is that Congress lawfully committed itself to the publication of an accurate record, and its failure to do so was itself unlawful rather than unconstitutional. In any event, plaintiffs did not base their claim on a violation of the legislative rule, and ultimately found no comfort in the Constitution. 
is free to dismiss suits by legislators to avoid separation of powers concerns, it often considers itself bound to at least reach the merits of suits brought by imdividuals. ${ }^{92}$

\section{III}

\section{Why Legislative Rules Are Special: The (UNSUCCESSFUL?) CASE FOR JUDICIAL DEFERENCE}

In Ballin, the Supreme Court aimed to establish a permanent framework within which the judiciary would have limited power to review legislative rules of procedure. In this it failed. Time after time, courts have expanded their power to hear these "sensitive" cases. But no court has succeeded, or for that matter attempted, to break down the barrier constructed in Ballin entirely. All cases presuppose some limit on the judiciary's power to review legislative rules of procedure.

This Comment takes a different tack. Rather than starting from the restrictive position first estabhished in Ballin and examining why the judiciary should play a more intrusive role in reviewing legislative rules, this Part starts from the other extreme. Why should the judiciary's role be limited at all? Why not treat validly enacted legislative rules like other statutes $?^{93}$ This intrusive review would not only include reviewing procedural rules for their constitutionality, but would also require the courts actually to interpret the rules and hear cases where plaintiffs allege misapplication of the rules in Congress. ${ }^{94}$ Such an approach would clearly

92. See infra text accompanying notes $125-57$ (discussing when the courts should reach the merits and when the claim should not even be entertained).

93. It should be noted that such review would not include the creation of legislative rules by the courts. It would only include reviewing those rules once Congress itself chose to adopt them. Even granting the extreme position, Ballin does properly exclude some material from judicial consideration:

Neither do the advantages or disadvantages, the wisdom or folly, of such a rule present any matters for judicial consideration .... [A]11 matters of method are open to the determination of the house, and it is no impeachment of the rule to say that some other way would be better, more accurate or even more just. It is no objection to the validity of a rule that a different one has been prescribed and in force for a length of time. The power to make rules is not one which once exercised is exhausted. It is a continuous power, always subject to be exercised by the house, and within the limitations suggested, absolute and beyond the challenge of any other body or tribunal.

United States v. Ballin, 144 U.S. 1, 5 (1892); see infra note 108 (discussing the sources of the legislature's inherent power to create procedural rules).

The "power" referred to im Ballin can be analogized to Congress' general ability to enact statutes. Even the strongest advocate of judicial review would not suggest that the judicial power imcludes the ability to enact statutes.

94. Congressmen have brought several cases challenging the application of a rule in Congress. See, eg., Vander Jagt v. O'Neill, 524 F. Supp. 519 (D.D.C. 1981), aff'd, 699 F.2d 1166 (D.C. Cir.), cert. denied, 464 U.S. 823 (1983), discussed at supra notes 74-82 and accompanying text. Or, a defendant in an enforcement proceeding could offer the invalidity of the statute's adoption as a defense, see, e.g., Ballin, 144 U.S. 1, discussed at supra notes 38-45 and accompanying text. 
involve the courts to an extent not yet legitimized in the cases.

It should be noted that the issue addressed in this Part is distinct froin the question of who should be allowed to bring these claims. Concluding that the courts should review rules of procedure freely is one thing. Concluding that any person could sustain such a suit is quite another. For exanple, wisdoin might dictate that legislators should not be permitted to raise issues of legislative procedure in court. But this pohicy would be based on the nature of the plaintiff and of the injury, not on the peculiarity of procedural rules. This distinction will be discussed in more detail in Part IV. ${ }^{95}$

Every discussion of judicial review of legislative actions inust begin with the well-estabhshed doctrine that "[i]t is, emphatically, the province and duty of the judicial department, to say what the law is."96 On its face, this bold proposition makes no distinction between the law as it is found in statutes and the law existing im procedural rules. The reinainder of this discussion seeks out the elusive justification for that distinctive treatment. In the search, I try to answer the simple question: why are legislative rules of procedure special?

\section{A. The "Textually Committed" Argument ${ }^{97}$}

The obvious place to start any examination of the rulemaking clause is the clause itself: "Each House may determine the Rules of its Proceedings."98 Does this clause vest Congress with exclusive jurisdiction to decide all questions relating to legislative rules of procedure? As is often the case when interpreting legislative text, more than one reading is possible. The clause could be read as setting aside legislative rules as the exclusive provimce of the legislature. On the other hand, an equally

Additionally, a plaintiff could claim that a legislative rule obligated Congress to act in a certain way, and Congress failed to do so. See, e.g., Gregg v. Barrett, 771 F.2d 539 (D.C. Cir. 1985) (holding that there is no first amendment right to a verbatim transcript of congressional proceedings); Christoffel v. United States, 338 U.S. 84 (1949), discussed at supra notes 57-64 and accompanying text.

95. See infra notes $125-57$ and accompanying text.

96. Marbury v. Madison, 5 U.S. (1 Cranch) 87, 111 (1803).

97. The phrase "textually committed" comes from the political question doctrine as enunciated in Baker v. Cárr, 369 U.S. ,186 (1962). That case lists the factors considered under the "political question" doctrine:

Prominent on the surface of any case held to involve a political question is found a textually demonstrable constitutional commitment of the issue to a coordinate political department; or a lack of judicially discoverable and manageable standards for resolving it; or the impossibility of deciding without an initial policy determination of a kind clearly for nonjudicial discretion; or the impossibility of a court's undertaking independent resolution without expressing lack of the respect due coordinate branches of government; or an unusual need for unquestioning adherence to a political decision already made; or the potentiality of embarrassment from multifarious pronouncements by various departinents on one question.

Id. at 217 (emphasis added).

98. U.S. CoNsT. art. I, $\S 5$, cl. 2. 
plausible reading of the text suggests that, while the Constitution grants to Congress the power to determine its rules initially, their interpretation and application are ultimately within the scope of the judiciary's article III powers. Both readings are plausible, but which reading is right?

The debates of the federal constitutional convention in 1787 fail to solve the mystery. The rulemaking clause does not appear in any of the draft constitutions presented in Philadelphia. ${ }^{99}$ In fact, the clause inakes its first appearance only in the Committee of Detail, ${ }^{100}$ where it appears to have been adopted with no discussion. ${ }^{101}$ Thus, because the text itself is inconclusive, we must turn elsewhere to discern its meaning.

What might have proinpted the framers to include the rulemaking clause in article I? Despite the ambiguous text and the lack of debate at the convention, if we can identify a purpose for the clause that would be defeated by judicial review of legislative rules, we might conclude that this textual coinmitment ousts the Court's jurisdiction. That is, the commitinent need not be found solely in the text; it can arise as well from purposes we read into the Constitution. ${ }^{102}$

In evaluating the inportance of possible rationales for the rulemaking clause, we should reinember the stakes. If we conclude that a particular rationale warrants the conclusion that the Constitution commits all matters concerning procedural rules to the legislative branch, we inust also conclude that the courts have no authority to hear the claim. This is true whether the plaintiff is a legislator or a private party, and whether the clain is that the rule violates the Constitution or merely that the legislature misinterpreted the rule. Thus, it is inportant to distinguish two similar, although ultimately very different, types of arguinents.

The first arguinent is that a concern is so inportant that it should lead us to conclude that the Constitution commits every aspect of procedural rulemaking to Congress. The second argument is that a given concern, although it does not preclude judicial review of procedural rules,

99. See, e.g., 1 J. Madison, The Debates in the Federal Convention of 1787 Which Framed the Constitution of the United States of America 18-31, 118-19 (G. Hunt ed. 1987). One possibility is that the framers simply borrowed the rulemaking clause from state constitutions, without further thought. See D. Hutchinson, THE Foundations of THE Constitution 64 (1975).

100. 2 J. MADison, supra note 99 , at 339.

101. Id. at 431 .

102. The Court in Baker v. Carr, 369 U.S. 186 (1962), referred to an issue's "textually demonstrable constitutional commitment . . . to a coordinate political department." Id. at 217 (emphasis added). But courts have not interpreted Baker to mean that the textual analysis should be limited to the constitutional text. Any persuasive evidence of a constitutional commitment sliould strip the judiciary of the authority to decide the issue. See, e.g., Powell v. McCormack, 395 U.S. 486, 521-47 (1969) (Court examines precedents of the English Parliament and American colonial assemblies, convention debates, state ratifying conventions, and congressional precedents in its inquiry into the constitutional commitment). 
warrants the development of discretionary judicial doctrines to limit the scope of that review. These discretionary doctrines can take many fornns, such as standing, ripeness, or narrow definitions of entitlements granted by legislative rules. The distinguishing feature common to these doctrines is that, unlike the doctrine resulting from the first argument, they do not bar all claims based on legislative rules.

\section{Separation of Powers Concerns}

The framers' understanding of the separation of powers clearly played some role in the inclusion of the rulemaking clause in article I. Exactly what role it played is more difficult to determine. This Section argues that, although judicial review of legislative rules imphicates separation of powers concerns, it does not do so to an extent justifying the conclusion that the Constitution commits procedural rules to the legislature exclusively. Instead, the primary thrust of the ruleinaking clause is to protect the legislature from the executive branch, not froin the judiciary.

The framers' conception of exactly what amounted to a proper division of powers einbraced several different theories. ${ }^{103}$ This Section will not attempt to review all these theories, because the Madisonian conception of separation of powers provides the most useful analytic focal poimt for the discussion.

James Madison forwarded both an affirmative and a negative forn of separation of powers. ${ }^{104}$ First, Madison argued that no branch of government should "possess, directly or indirectly, an overruling influence over the others in the administration of their respective powers."105 Second, and just as important, the appropriate division of powers could be ensured by "giving to those who admimister each department the necessary constitutional means and personal motives to resist encroachinents of the others."106 A system of separated powers should allow each branch to fight for its own interests and should prohibit any branch from unduly interfering with the exercise of another branch's authority.

It is easy to see a relationship between the positive aspect of separation of powers and the rulemaking clause, because, without procedural rules, Congress would be unable to exercise its legislative function. The

103. See, e.g., W. GWyn, The Meaning of the Separation of Powers (1965). Gwyn identifies a number of purposes underlying the separation of powers doctrine, including creating greater governmental efficiency, assuring that statutory law is made in the common interest, assuring impartial lawmaking, and allowing the people's representatives to call executive officials to account. Id. at 127-28.

104. Comment, The Limits of Popular Sovereignty: Using the Initiative Power to Control Legislative Procedure, 74 CALIF. L. REV. 491, 533-34 (1986) (authored by James E. Castello).

105. The Federalist No. 48, at 308 (J. Madison) (C. Rossiter ed. 1961).

106. Id. No. 51, at 321-22. 
nature of this relationship, however, is less clear. To what extent must we protect absolute legislative autonomy in rulemaking in order to preserve the positive notion of the separation of powers?

The extreme answer is-not at all. According to this view, who makes the rules is irrelevant; the existence of the rule is the only important matter. This approach has been rejected by almost all commentators on the legislative process. Justice Story, for example, argued that:

No person can doubt the propriety of the provision authorizing each house to determine the rules of its own proceedings. If the power did not exist, it would be utterly impracticable to transact the business of the nation, either at all, or at least with decency, debiberation, and order. The humblest assembly of men is understood to possess this power, and it would be absurd to deprive the councils of the nation of a like authority. ${ }^{107}$

Story's argument is based on practical considerations, but others have cast the argument in normative terms-identifying the power to make rules as an inherent power flowing from the right of self-government. ${ }^{108}$ Thus, at the very least, it appears that the rulemaking clause in article I amounts to a textual commitment to Congress of the power to create legislative rules of procedure. Such authority belongs to the legislature inherently, whether for practical or normative reasons, and functions to preserve the positive conception of the separation of powers.

The positive conception of the separation of powers demands no more than this. The Constitution grants Congress the exclusive power to adopt legislative rules and repeal those rules found to be unworkable. Judicial review of legislative rules does not significantly implicate the positive conception of the separation of powers. It does not hamstring Congress, nor make Congress an easy mark for the other branches. To the extent that judicial review in this area does weaken Congress, it does so in exactly the same way that judicial review of statutes generally weak-

107. 1 J. StoRy, Commentaries on the Constitution of THE United States $§ 837$ (1873).

108. Jefferson would agree with this inherent power argument:

Every man, and every body of men on earth, possesses the righ [t] of self-government: they receive it with their being from the hand of nature. Individuals exercise it by their single will: collections of men, by that of their majority; for the law of the majority is the natural law of every society of men. When a certain description of men are to transact together a particular business, the times and places of their meeting and separating depend on their own will; they make a part of the natural right of self-government. This, like all other natural rights, may be abridged or modified in [its] exercise, by their own consent, or by the law of those who depute them, if they meet in the right of others: but so far as it is not abridged or modified, they retain it as a natural right, and may exercise it in what form they please, either exclusively by themselves, or in association with others, or by others altogether, as they shall agree.

17 The Papers of Thomas Jefrerson 95 (J. Boyd ed. 1965) (emphasis in original) (footnotes omitted). 
ens the legislative branch. ${ }^{109}$

Similarly, the negative separation of powers concerns that motivated the adoption of the constitutional rulemaking clause allow judicial review of procedural rules. These concerns require only a narrowly defined right of the legislature to adopt rules necessary to carry on legislative affairs.

The framers' negative separation of powers concerns focused on the conflict between the legislative and executive branches, not the legislative and judicial branches. Specifically, the primary concern was that the executive, if given the power to control the legislature's procedural rules, would succeed in dominating it. ${ }^{110}$ This possibility led to a policy of "insulating the judiciary and particularly the legislature from executive manipulation." 111 The rulemaking clause was but one example of this pohicy, an attempt to exclude the executive from the legislature's deliberative process. ${ }^{112}$

This rationale does not extend to the review of legislative rules by the judiciary. No court would have any preemptive power over the legislative process. Instead, the courts would be empowered only to review pieces of legislation for compliance with Congress' voluntarily adopted rules, or to review those rules for compliance with the Constitution. Again, the separation of powers concerns implicated by sucl a proposition are merely those concerns implicated by the general process of judicial review. Once the legislature's authority to create rules is established, no additional separation of powers rationale exists for excepting rules

109. In fact, if anything, judicial review of legislative rules might pose less of a theoretical problem than judicial review of a substantive piece of legislation. A court that deems a substantive statute unconstitutional or interprets a piece of legislation exercises authority over what is, in some sense, the "will of the people." This, to some scholars, gives rise to a counter-majoritarian dilemma. See, e.g., A. Bickel, The Least Dangerous Branch 16-23 (1986) ("The root difficulty is that judicial review is a counter-majoritarian force in our system."); J. ELY, DEMOCRACY AND DISTRUST (1980). Legislative rules, on the other hand, are considered more closely akin to rules of convenience than volitional choices of the electorate. This distinction has been recognized by others. Indeed, Jefferson, in positing the inherent right of Congress to create its own procedural rules, rehed on the legislature's right of self-government. See supra note 108 . This theoretical basis clearly presupposes some distinction between the creation of legislative rules (which Congress rightfully creates for itself as a democratic institution) and the creation of substantive legislation (which Congress rightfully creates as an agent in a larger democratic institution).

110. This concern was a transplant from the British political experience. See Comment, supra note 104, at 530-33. The desire to avoid an omnipotent executive was carried to the extreme in the Virginia Constitution. See Letter of Thomas Jefferson (July 1816), cited in J. POLE, Polmical REPRESENTATION IN ENGLAND AND THE ORIGINS OF THE AMERICAN REPUBLIC 169-338 (1971); VA. CONST. of 1776, If 5, 7; see also Comment, supra note 104, at 533-39 (discussing how the relationship between the legislature and the exeeutive shaped the rulemaking clause).

111. G. WoOd, The CREation OF THE AMERICAN Republic 157 (1969).

112. See B. BaIlyn, The Ideological Origins of the AMErican Revolution 144 (1967) (noting that some of the important "attitudes and ideas that would constitute the Revolutionary ideology ... . were the fear of corruption-of its anticonstitutional destructiveness-and of the menace of a ministerial conspiracy"). 
promulgated under the rulemaking clause from the long-accepted process of judicial review. ${ }^{113}$

\section{The Preservation of a Bicameral Legislature}

The idea of bicameralism played a major part in colonial constitutional debates. One recent comment on legislative rules and popular sovereignty identified three aspects of bicameralism that may have prompted the rulemaking clause. ${ }^{114}$ As we will see below, judicial review of legislative rules implicates none of these concerns to such an extent that it should oust the courts' power to review.

First, the simple mechanics of government justified the rulemaking clause. The clause gives each house the right to determine the rules of its proceedings. The clause may have been simply a recognition of the fact that the Senate and the House of Representatives, because they perform shightly different tasks, may need different rules. The clause empowers each house to determine those rules most conducive to its particular style of deliberation. ${ }^{115}$ While such a consideration might prevent the courts from formulating those rules, it should not prevent the courts from adjudicating the rules once they are adopted.

Second, the framers saw bicameralism as a particular way of effectuating the separation of powers. ${ }^{116}$ The rulenaking clause preserves the division of powers among the three branches by inaking a unified legislative attack on a coordinate branch more difficult. Madison argued that the only powerful check on the three powers is within the legislature. ${ }^{117}$. Judicial review of legislative rules has no effect on this interest.

Finally, the grant of rulemaking authority to each house independently ensures that the bicameral system remains bicameral. ${ }^{118}$ Thomas Jefferson observed that " "[t]he purpose of establishing different houses of legislation is to introduce the influence of different interests or different principles." "119 The rulemaking clause helps preserve this "division of interests." 120 Again, however, judicial review of procedural rules inde-

113. There may, however, be separation of powers concerns that justify the exercise of discretion by the courts. See infra notes $125-57$ and accompanying text.

114. Comment, supra note 104 , at 543-47.

115. Id. at 543 .

116. Id. at 543-45.

117. G. WILls, ExplainiNg AMERICA: ThE FEderalist 122 (1981) ("For [Madison] there is only one powerful check in the three powers, and that is within the legislature. If it restrains itself, the other two will be safe. If it does not restrain itself, they are helpless against it.") (emphasis in original).

118. Comment, supra note 104 , at 545-47.

119. Id. at 545 (quoting T. JefFerson, Notes on the State of Virginia, in WRITINGS 245 (M. Peterson ed. 1984)).

120. W. GWYN, supra note 103 , at 23-25.

It has often been said that the doctrine of the separation of powers developed out of that of 
pendently adopted by each house has little impact on this bicameral interest.

This Section has reviewed the text of the rulemaking clause, the debate at the constitutional convention, and the possible rationales behind the adoption of the rulemaking clause. None of these sources evimces an intent to exempt the legislative rules from the purview of the judiciary. At best, what we find is an intent to empower each house of Congress to adopt rules of procedure on its own. Of course, such an inquiry is not dispositive. We may still determme that legislative rules should not be reviewed by the courts. The following Sections examine other reasons offered for the special treatment of legislative rules.

\section{B. The Judicial Competence Argument}

Another arguinent made for the proposition that courts should not review legislative rules is that no standards exist by which such rules could be judged. ${ }^{121}$ For example, Judge Bork referred to "the very real problem of a lack of judicial competence to arrange complex, orgamic, political processes within a legislature so that they work better."122 Considering the legislative veto, one writer noted the consequences of the judiciary's meddling in the legislative process: "The inevitable result is a record of non-compliance, subtle evasion, and a system of lawmaking that is now more convoluted, cumbersome, and covert than before."123

It is difficult to see how these criticisms apply to legislative rules of procedure. Once the legislature adopts a procedural rule, the judiciary's role is either to interpret the rule according to normal principles of statutory interpretation, or to determme whether the rule is constitutionalan unextraordinary exercise in constitutional adjudication. There is no

the mixed constitution .... [But] the fact remains that the two doctrines are different in both content and origin. The separation of powers is based on an analysis of governmental functions; mixed monarchy on the "three estates," two of which are social groups, participating in the political process .... The one can exist with unicameralism; the other, as understood in Britain, requires a bicameral legislature.

Id. at 26-27.

James Castello noted that:

Blackstone also emphasized the relationship of bicameralism to the development of separate privileges in each house of Parliament. In his gloss on Sir Edward Coke's assertion that a matter should only "be examined, discussed, and adjudged in that house to which it relates," Blackstone explained: "Hence for instance, the lords will not suffer the cominons to interfere in settling a claiun of peerage; the commons will not allow the lords to judge the election of a burgess; nor will either house permit the courts of law to examine the merits of either case."

Comment, supra note 104, at $545-46$ n.290 (citations omitted).

121. See Baker v. Carr, 369 U.S. 186, 217 (1962) (lack of judicially discoverable and nanageable standards for resolving an issue is one characteristic of a "political question").

122. Vander Jagt v. O’Neill, 699 F.2d 1166, 1182 (D.C. Cir. 1983) (Bork, J., concurring).

123. Fisher, Judicial Misjudgments About the Lawmaking Process: The Legislative Veto Case, 45 PuB. ADMIN. REv. 705, 710-11 (1985). 
reason to suspect that the courts will, in either case, encounter difficulties not present when the courts consider substantive statutes.

The Constitution does not grant the legislative branch absolute autonony in the field of legislative rules of procedure. At most, it empowers each house of Congress to adopt rules independently of each other and the executive branch. Once the rules are adopted, the constitutional concerns fade. Thus, the special treatinent of legislative rules must be justified by other concerns, and inust spring not froin a constitutional coinmand but froin the discretion of the judiciary. ${ }^{124}$ Those who wish to limit judicial interference in the affairs of the legislative branch have no reason to fear this judicial power, however. A doctrine exists that shields the legislature from the judiciary's meddling. That doctrine is the subject of Part IV.

\section{IV}

\section{Why Legislative Rules $A$ Re SPecial: The "Political" POLITICAL QUESTION DOCTRINE}

The Ninth Circuit traced the special treatment of legislative rules to the desire to avoid "a perversion of the judicial process into a political process." 125 In fact, exactly the opposite is true. Courts should be wary of undue interference with legislative rules for fear that they will turn the political process into a judicial one. Legislative rules regulate the ways in which legislation can be raised, considered, and decided. But they do not do so in a neutral way. Instead, they are an integral part of the political process, and do not aim to provide a level playing field. ${ }^{126}$

Recognition of the political nature of legislative rules changes the analysis of their justiciability. Courts should defer to the legislature not because the Constitution commits the rulemaking power to that branch, not because the courts are unable to deal with legislative rules, and not because the mere consideration of rules by the court would disrupt the separation of powers. Instead, courts should avoid considering legisla-

124. It is not extraordinary to assume that the Constitution gives the issue to the courts, but that the courts should in turn exercise restraint. This is especially trne where the claim is likely to be brought by a legislator. See, e.g., Riegle v. Federal Open Mkt. Comm., 656 F.2d 873, 881 (D.C. Cir.), cert. denied, 454 U.S. 1082 (1981) ("In short, a clear constitutional or statutory prohibition of judicial review will surely not be present in many cases where prudential concerns nevertheless warrant a court in finding it improper for a congressional plaintiff to invoke the judicial power.").

125. Davids v. Akers, 549 F.2d 120, 124 (9th Cir. 1977).

126. The Supreme Court has, in other contexts, recognized purely political motives. In Gaffney v. Cummings, 412 U.S. 735 (1973), for example, the Court declined to modify a Connecticut gerrymander claimed to be "invidiously discriminatory because a 'political fairness principle' was followed." Id. at 752. Justice White's majority opinion recognized the "reality . . . that districting inevitably has and is intended to have substantial political consequences." Id. at 753. Similarly, the political nature of legislative rules should not be ignored. 
tive rules because by domg so, they turn those rules into something they are not: enforceable norms.

Section A discusses how the inherently political nature of procedural rules affects the justiciability of claims by legislators. Section B contrasts the position of a private party with that of a legislator, arguing that the "political" pohtical question doctrine cannot justify the courts' refusal to hear private party claims. Section $\mathbf{C}$ discusses a difficult "hybrid" case and the courts' recent efforts to resolve the problem.

\section{A. Suits Brought By Legislators}

In Cohens v. Virginia, ${ }^{127}$ Chief Justice Marshall declared:

[T] his court ... must take jurisdiction, if it should. The judiciary cannot ... avoid a measure, because it approaches the confines of the constitution .... We have no more right to decline the exercise of jurisdiction which is given, than to usurp that which is not given. The one or the other would be treason to the constitution. ${ }^{128}$

It might seein unusual, then, to suggest that courts fashion discretionary doctrimes to exclude froin judicial cognizance claims brought by legislators. This Section argues that the political nature of legislative rules of procedure compels just that result. The judiciary should refuse to hear those cases in which a congressional plaintiff challenges the application of legislative rules. Hearmg such cases would inject judicial decisionmaking into a purely pohitical umiverse.

Consider two possible cases. In one, a legislator claims that a bill, already considered and enacted, should be deemed invalid because its consideration by Congress violated an internal legislative rule. In another, a legislator challenges the constitutionality of a rule of legislative procedure. How does the political nature of legislative rules affect the outcome of these cases?

In the first case, a court should refrain from granting relief. Because legislative rules are so flexible, ${ }^{129}$ they do not limit the consideration of legislation in a inanner that restricts the preferences of the legislators. If a bill is destined to pass, it will pass under any system of rules in effect. Thus, at inost, a court's grant of relief will simply give the complaining legislator a second chance to fight the bill-this time in the judicial arena-even though the legislator suffered no disadvantage on the first go-round.

127. 19 U.S. (6 Wheat.) 120 (1821).

128. Id. at 181. Similarly, Professor Wechsler notes that "[t]he courts have both the title and the duty when a case is properly before them to review the actions of the other branches in the light of constitntional provisions." Wechsler, Toward Neutral Principles of Constitutional Law, 73 HARV. L. REV. 1, 19 (1959).

129. See supra notes $16-26$ and accompanying text. 
In the second case, where the legislator challenges the constitutionahty of a procedural rule, a court is the least appropriate forum to address the alleged injury. A legislator's defense against the adoption of unconstitutional rules is to fight their adoption in the legislature. Once that battle is lost, the legislator suffers no injury distinct from the injury suffered by the citizenry as a whole when an unconstitutional statute exists. ${ }^{130}$

Because legislative rules are political in nature, the grant of relief in either case would interfere with political decisions made in a political context. Absent some affirmative reason forcing a court to grant rehef, ${ }^{131}$ a court should avoid becoming a forum for a "rematch" of a political contest.

Soine courts have dealt with the problem of legislative plaintiffs through use of the standing doctrine. The court in Riegle v. Federal Open Market Committee ${ }^{132}$ noted that "[w]hen congressional plaintiffs have sought to accoinplish in this court what they were unable to persuade their colleagues to do, we have usually refused to confer standing because of our concern for non-interference in the legislative process." 133 Whatever the inerits of this treatment in the general context of legislative standing, use of the standing doctrine is especially inapposite in the context of legislative rules of procedure.

First, apphication of the standing doctrine in the context of legislative rules violates two of the basic tenets of that doctrine. Virtually all congressional standing cases are founded upon two fundamental principles: Courts apply no special standards to congressional standing cases $^{134}$ and the congressional plaintiff must have suffered an injury that cannot be redressed by his fellow legislators. ${ }^{135}$ The problem is that every injury based on the misinterpretation or unconstitutionality of a legislative rule can be redressed within the legislature. ${ }^{136}$ Nowhere but in this special rule of legislative standing must a plaintiff demonstrate that only the court could provide relief. Thus, even after the standing

130. The mere existence of an unconstitutional statute has never been enough to make a claim justiciable. See, e.g., Boyle v. Landry, 401 U.S. 77, 81 (1971) (dismissing a claim that a statute was unconstitutional in the absence of any showing that plaintiffs were at risk of being prosecuted under it).

131. See infra notes $154-57$ and accompanying text (discussing what circumstances might make judicial relief appropriate).

132. 656 F.2d 873 (D.C. Cir.), cert. denied, 454 U.S. 1082 (1981).

133. Id. at 877 .

134. Harrington v. Bush, 553 F.2d 190, 204 (D.C. Cir. 1977).

135. See McGowan, Congressmen in Court: The New Plaintiff, 15 GA. L. REv. 241, 254 (1981).

136. This is not the case in the general congressional standing case. Some injuries may arise from an act of the executive branch and as a result cannot be redressed within the legislature. See, e.g., Goldwater v. Carter, 617 F.2d 697 (D.C. Cir.) (en banc) (challenging President's right to terminate a treaty without consent of the legislature), vacated mem., 444 U.S. 996 (1979); Kennedy v. Sampson, 511 F.2d 430 (D.C. Cir. 1974) (case involving illegal pocket veto). 
inquiry, the question of why legislative rules demand special treatment remains. Standing doctrine may effectively dispose of these cases, but it does not explain them.

Second, the special redressability requirement used to deny standing to legislators challenging procedural rules has not been applied to cases where a legislator challenges executive action. For example, in Kennedy v. Sampson, ${ }^{137}$ the court held that a legislator would have standing where his vote was impaired by the allegedly unlawful conduct. ${ }^{138}$ The court never discussed the possibility that Senator Ke1medy's colleagues might have been able to provide the necessary rehef. ${ }^{139}$ Agam, standing doctrine itself does little to explain the exceptional treatment of legislative rules. While standing doctrine may help distinguish between congressional and third-party plamtiffs, it does nothing to explain why congressional plamtiffs should be able to raise soine claims but not others. ${ }^{140}$

Finally, use of the standing doctrine imisplaces the proper emphasis of the analysis. In Allen v. Wright, ${ }^{141}$ the Supreme Court noted that "[t]he law of [Article] III standing is built on a single basic idea-the idea of separation of powers." ${ }^{142}$ But as we noted earher, judicial review of legislative rules does not seriously imphicate separation of powers concerns. Any discussion of the justiciability of legislative rules of procedure should properly einphasize the political nature of those rules. The conventional application of standing rules, founded as they are on separation of powers concerns, necessarily clouds the analysis. Thus, standing doctrine inevitably fails as a means of explaining why congressional plaimtiffs should be barred froin bringing claims based on alleged violations of procedural rules.

The inere fact that congressional plaintiffs have standing to bring claims does not necessarily inean that the court inust grant relief. The judiciary should, in recognition of the political nature of legislative rules,

137. 511 F.2d 430 (D.C. Cir. 1974).

138. Id. at $435-36$.

139. One alternative might have been for Congress to stall controversial bills passed immediately before a recess, and send them to the White House only after Congress reassembled. Former majority leader Mansfield apparently used this device. See N.Y. Times, Nov, 10, 1974, § 1, at 44, col. 1; see also P. BAtor, D. Meltzer, P. Mishkin, \& D. Shapiro, Hart \& Wechsler's THE Federal Courts aNd the Federal System $158 \mathrm{n} .8$ (3d ed. 1988) (discussing congressman's lack of standing in Riegle v. Federal Open Market Committee, 656 F.2d 873 (D.C. Cir. 1981)).

140. For example, why would a legislator have standing in Kennedy (court held that senator had standing to challenge allegedly invalid pocket veto), but not in a case like Gregg (complaint by congressional plaintiff alleging that congressional record was inaccurately prepared dismissed under doctrine of remedial discretion)?

141. 468 U.S. 737 (1984).

142. Id. at 752 . 
utilize its broad equitable powers to withhold injunctive or declaratory relief. $^{143}$

\section{B. Suits Brought By Private Parties}

Courts liave recognized that "an important reason to withhold equitable relief for congressional plaintiffs is the possibility that other, private plaintiffs may bring suit im a context less laden with separation-of-powers concerns." ${ }^{144}$ Early on, the Supreme Court noted the importance of protecting nonparticipants in the political process. In United States $v$. Smith, ${ }^{145}$ the Court noted that, "As the construction to be given to the rules affects persons other than members of the Senate, the question presented is of necessity a judicial one." 146 More recent cases have echoed this general idea. ${ }^{147}$

Private-party plaintiffs tlius receive different treatment than do congressional plaintiffs. Still, private-party plaintiffs cannot raise claims concerning legislative rules in every case or simply challenge the constitutionality of legislative rules on their own. ${ }^{148}$ If one applies the "political" political question doctrine to the private-party plaintiffs' claims, one gets a good idea of what claims they could bring, and when.

Consider three possible scenarios. First, a private party in a civil or criminal enforcement proceeding challenges the validity of a law enacted in alleged violation of a legislative rule. ${ }^{149}$ Second, a private party in an

143. This doctrine has been adopted in slightly different form in Riegle v. Federal Open Market Committee, 656 F.2d 873, 881 (D.C. Cir.), cert. denied, 454 U.S. 1082 (1981). The court stated in that case:

[This] standard would counsel dismissal of a congressional plaintiff's claim in cases concerning legislative action or inaction because it is in these cases that the plaintiff's dispute appears to be primarily with his fellow legislators .... . Judges are presented not with a chance to mediate between two political branches but rather with the possibility of thwarting Congress's will by allowing a plaintiff to circumvent the processes of democratic Id. deeisionmaking.

Riegle is in accord with the analysis undertaken in McGowan, supra note 135, at 262 ("the best way to translate [these separation of powers] concerns into principled decisionmaking is through the discretion of the federal court to grant or to withhold injunetive or declaratory relief ").

144. Gregg v. Barrett, 771 F.2d 539, 546 (D.C. Cir. 1985) (citations omitted).

145. 286 U.S. 6 (1932).

146. Id. at 33 .

147. See, e.g., Yellin v. United States, 374 U.S. 109, $115-17$ (1963) (interpreting legislative rule to protect private parties); Christoffel v. United States, 338 U.S. 84, 87-88 (1949) (interpreting legislative quorum rule to determine if plaintiff testified falsely before a "coinpetent tribunal"); Gregg, 771 F.2d 539 (court reached the merits of claim brought by private parties, while dismissing congressional plaintiffs' claim); Pauling v. Eastland, 288 F.2d 126, 130 (D.C. Cir.), cert. denied, 364 U.S. 900 (1960) (court may pass upon validity of legislative order if plaintiff is convicted of contempt for failing to obey it).

148. See Boyle v. Landry, 401 U.S. 77, 80-81 (1971) (mere existence of polentially unconstitutional statutes will not sustain suit).

149. See, e.g., United States v. Smith, 286 U.S. 6 (1932). 
enforcement proceeding challenges the validity of a law enacted in accordance with an allegedly unconstitutional procedural rule. ${ }^{150}$ Third, a private party claims that a rule representing a grant by Congress to individuals of a right or privilege has been misinterpreted or misapplied. ${ }^{151}$ Different consequences result in each of these cases.

In the first case, the courts should not grant relief to the privateparty based upon the misapplication of the procedural rule. In this context, a private party is in the same position as the disgruntled legislator; rehief would only inean granting a second crack at the legislative process. In part, the court's hesitation to act should follow froin a recognition that the remedy requested will simiply have no effect, because the legislature will inerely reenact the statute according to proper procedure. More important, however, should be the recognition that forcing Congress to retrace its steps ainounts to a particularly heinous showing of disrespect for a coordinate branch. It is in this situation that the separation of powers implications of judicial review of legislative rules are most powerful.

Furthermore, allowing dissatisfied private parties to challenge any alleged misinterpretation of a legislative rule would inevitably lead to a mass stampede to the courthouse. Congress passes every piece of legislation pursuant to legislative rules. Every piece of legislation would therefore be subject to attack. As the District of Columbia Circuit predicted in Metzenbaum v. Federal Energy Regulatory Commission, 152 "[t]o decide [to review legislative rules] would subject Congressional enactinents to the threat of judicial invalidation on each occasion of dispute over the content or effect of a House or Senate rule."153 The appropriate remedy for the unhappy constituent in this kind of case rests in the political branches, not the judiciary.

In the second case, the courts should be willing to provide relief. Legislators have the responsibility to consider, and do consider, the constitutionality of the statutes they enact. ${ }^{154}$ Private parties bringing the claim have no such privilege. A private party's only opportumity to raise the constitutionality of a procedural rule arises after Congress adopts the rule, and after a situation has already arisen in which the rule is applied.

150. See, e.g., United States v. Ballin, 144 U.S. 1 (1892), discussed at supra notes $38-45$ and accompanying text.

151. See, e.g., Christoffel, 338 U.S. 84; Yellin, 374 U.S. 109, discussed at supra notes $57-73$ and accompanying text.

152. 675 F.2d 1282 (D.C. Cir. 1982).

153. Id. at 1287.

154. Congress' ability to do so competently has not been recognized universally. See, eg., Mikva, How Well Does Congress Support and Defend the Constitution?, 61 N.C.L. REv. 587, 587 (1983) ("[A]t best, Congress does an uneven job of considering the constitutionality of the statutes it adopts."). Other commentators are more positive. See, e.g., Fisher, Constitutional Interpretation by Members of Congress, 63 N.C.L. REv. 707, 708 (1985) ("Congress can provide an essential, broad, and ongoing role in shaping the meaning of the Constitution."). 
Moreover, judicial cognizance of this kind of claim demonstrates no disrespect for the judgment of a coordinate branch. The unconstitutional effects of a given procedural rule may not be apparent to the legislature upon the rule's adoption; the effects may only arise once the rule has been applied in a concrete situation and the chain of events has played itself out. Judicial review in this context allows Congress to consider the full effects of its legislative rules and shape them in accordance with constitutional commands.

It should be noted that where a private party in an enforcement proceeding challenges the constitutionality of a legislative rule, the interest of the private party is especially compelling. ${ }^{155}$ The special status of those subject to enforcement proceedings has been recognized in many contexts. ${ }^{156}$ Only in the inost extreine circumstances should a court refuse to decide a constitutional issue raised in an enforcement proceeding.

In the last kind of case, a private party claims that Congress failed to provide a privilege or right granted in a legislative procedural rule. In such cases, private parties have a due process right to have their claims heard in court. This right applies whether or not the claims are raised while the individual is a defendant in an enforceinent proceeding. The political nature of the rule gives way to its function as a nonpolitical guarantee of individual protections. Indeed, by adopting these kinds of privileges (altlıouglı in the guise of procedural rules), Congress implicitly recognizes that procedural rules create such privileges. Furthermore, the purpose of enacting these kind of rules is to segregate soine interests from the pohitical process. The intent of Congress should be enough to merit judicial review. ${ }^{157}$

155. Cf. Hart, The Power of Congress to Limit the Jurisdiction of Federal Courts: An Exercise in Dialectic, 66 HARV. L. REV. 1362, 1375-79 (1953) (discussing the constitutional problems with civil enforcement actions).

156. See, e.g., Lipke v. Lederer, 259 U.S. 557, 561-62 (1922) (retail liquor licensee subject to criminal penalty involviug seizure of property for violation of prohibition law is entitled to relief by a hearing and an injunction); Ng Fung Ho v. White, 259 U.S. 276, 282-85 (1922) (immigrants subject to deportation who clained citizenship based on evidence before iminigration officer and a petition for habeas corpus were entitled to a judicial hearing of the clain under the fifth amendment); Wong Wing v. United States, 163 U.S. 228, 233-38 (1896) (innigrants subject to deportation pursuant to a statute providing for hard labor and confiscation of property are entitled to a hearing); see also Estep v. United States, 327 U.S. 114, 120 (1946) ("[T]he silence of Congress as to judicial review is not necessarily to be construed as a denial of the power of the Federal courts to grant relief.... Judicial review nay indeed be required by the Constitution."); Falbo v. United States, 320 U.S. 549, 554-55, reh'g denied, 321 U.S. 802, reh'g denied, 322 U.S. 770 (1944) ("Even if there were . . a a constitutional requirement that judicial review inust be available to test the validity of the decision of the local [draft] board ... the conıplete abseuce of any provision for such challenges ... permits no other inference than that Congress did not intend that they could be made.").

157. Of course, one might argue that Congress grants rights and privileges through legislative rules only to the extent that it actually chooses in any given case to be bound by those rights and privileges. This "bitter with the sweet" argument has been rejected in cases where Congress grants 


\section{C. "Hybrid" Cases: Hastings and Nixon}

Thus far, this Comment's theory has envisioned two types of actors: legislators and third parties. The "pohtical" political question doctrine suggests that courts should not grant relief where legislators bring claims based on procedural rules, but should be free to do so where third parties bring similar claims. This theory recognizes the inappropriateness of judicial interference in purely political battles. The theory also acknowledges, however, the need to place soine limits on congressional attempts to determine the rights and habilities of private parties. These two interests can be reconciled only by recognizing the peculiarly political nature of legislative rules of procedure.

In the recent impeachment proceedings of foriner federal judges Alcee Hastings ${ }^{158}$ and Walter Nixon, ${ }^{159}$ the courts created a third category: the nonlegislator in the legislative arena. Hastings and Nixon challenged the constitutionality of Rule XI of the Rules of Procedure and Practice im the Senate When Sitting on Inpeachinent Trials. ${ }^{160}$ Rnle XI provides for the appointinent of a Senate Committee "to receive evidence and take testimony" and to "report to the Senate in writimg a certified copy of the transcript of the proceedings and testimony had and given before such committee." 161 Proceedings before the committee are videotaped, and Senators are given approximately one inonth to read the committee report and review the tapes before voting for or against impeachment. ${ }^{162}$ Also, as the court in Hastings noted, "Rule XI specifically reserves to the Senate as a whole the right to hear directly the testimony of any or all witnesses it desires at any time prior to the impeachment vote." 163

Hastings and Nixon contended that Rule XI violated article I, section 3, clause 5 of the Constitution, which provides that "[t]he Senate shall have the sole power to try all impeachments." 164 According to Nixon and Hastings, the Senate must literally try all impeachments. That is, the Senate inust conduct a trial in front of the entire Senate, and the Senate as a whole must serve as judge and jury. Inforination sifted

rights and privileges by statute and should not be revived in this context. See Cleveland Bd. of Educ. v. Loudermill, 470 U.S. 532, 541 (1985).

158. Hastings v. United States Senate, Impeachment Trial Comm., 716 F. Supp. 38 (D.D.C.), aff'd, 887 F.2d 332 (D.C. Cir. 1989). Judge Nixon intervened in the Hastings proceeding, having demonstrated that he would face similar impeachment hearings in the Fall of 1989.

159. Nixon v. United States, 744 F. Supp. 9 (D.D.C. 1990).

160. See S. Doc. No. 3, 101st Cong., 1st Sess. 15 (1989).

161. Id.

162. See S. ReP. No. 1, 101 st Cong., 1st Sess. 112 (1989); Hastings, 716 F. Supp. at 40.

163. Hastings, $716 \mathrm{~F}$. Supp. at 40.

164. U.S. CoNST. art. I, $\S 3$, cl. 5. 
through a committee, the argument ran, does not satisfy the constitutional requirement.

Nixon introduced statistical evidence at trial suggestimg that his complaint ainounted to inore than mere quibblimg over some arcane procedural nicety. The evidence showed that

one of the two counts on which he was convicted and all of the eight counts on which former Judge Hastings was convicted failed to receive a two thirds majority of committee meinbers and thus inight not have received such a majority in the full Senate had all of the Senators heard the evidence directly. ${ }^{165}$

The evidence suggested that Rule XI had a possibly determinative effect on the impeachment proceedings.

Ultimately, the courts in both cases held that the disputes were nonjusticiable, but the courts did so in rather odd opimions. Judge Gesell in Hastings appeared ready after a brief discussion to deny the claim on the merits, but added almost as an afterthought that the claim was simply nonjusticiable. By contrast, Judge Oberdorfer in Nixon seemed poised after a detailed analysis of the constitutional provision to reject Rule XI and the Senate's interpretation of the constitutional requirement. But again, seemingly out of the blue, the court concluded that the clain was not justiciable. The former judges could not look to the judiciary for relief.

In Hastings, Judge Gesell began by noting the limited scope of his inquiry: "It is crystal clear that impeachment proceedings are wholly committed to Congress under the Constitution. Thus a classic political question is presented .... Absent evidence that the Senate is violating the Constitution, the Court should stay its hand."166 After noting that "[t]he use of a cominittee to develop facts is not a new idea," the court concluded that: "The Constitution does not say that the full Senate inust try all impeachments, nor does the verb 'try' necessitate granting the accused all the requirements of nodern criminal due process as the complaining judges suggest."167 The court appeared to have accomplished its simple task. It reviewed the procedural rule for compliance with the language of the Constitution and, deferring somewhat to the Senate interpretation, concluded that the rule was in fact constitutional. Unfortunately, Judge Gesell did not stop there. The court, noting that it "refused to second-guess the Senate's impeachment proceedings," "168 held

165. Nixon, 744 F. Supp. at 11.

166. Hastings, 716 F. Supp. at 40.

167. Id. (emphasis in original).

168. Id. at 41 . 
the dispute nonjusticiable. ${ }^{169}$ Like the court in United States v. Ballin, ${ }^{170}$ the district court simply refused to reach the matter at all.

At least initially, the court in Nixon took a inarkedly different approach. After an exhaustive review of the historical sources, the court concluded that "if the Framers could speak today, they might well say that they intended inipeachments to be tried to the Senate, sitting as a court on questions of law and as jurors on questions of fact."171 Indeed, Judge Oberdorfer suggested that the framers wanted to inake inipeachment more difficult, and chose trial by the entire Senate as a particularly effective means of achieving that goal. ${ }^{172}$

Judge Oberdorfer quickly shifted gears near the end of the opinion. Concluding that Rule XI violates the constitutional requirements of article I, he opined:

Despite textual and historical indicators that the word "try" carries with it some duty for Senators to sit as judge and jury, and appealing as plaintiff's functional argument may be, plaintiff has not established the kind of clear violation of a specific constitutional requirement which would trigger judicial authority to review a solemn and serious Senate action. Even though plaintiff's challenge to the constitutionahty of Rule $\mathrm{XI}$ raises a serious question not yet addressed at the appellate level, it must nonetheless fail because his claim is not justiciable. ${ }^{173}$

The court once again refused to review the constitutionality of a legislative rule of procedure.

As noted earlier, the "pohtical" political question doctrine envisions a world inhabited by two types of actors: legislators and third parties. Judge Oberdorfer's opimion created a third type of actor. Foriner Judge Nixon was clearly not a legislator. But, according to Judge Oberdorfer, the Senate need not treat him as they would a nonofficial third party whose rights outside the halls of Congress were being threatened by the procedural rule. Judge Oberdorfer concluded that

the instant controversy might be justiciable and plaintiff might be entitled to the relief he seeks if he had not been impeacleed by the House, were not a civil officer of the United States, or if the Senate liad attempted to inpose a sanction beyond removal from office and disqualification froin

169. Id. at 43.

170. 144 U.S. 1 (1892). For a discussion of Ballin, see supra notes $38-45$ and accompanying text.

171. Nixon, 744 F. Supp. at 12.

172. Id. Quoting Alexander Hamilton, Judge Oberdorfer noted that " " $t$ ]he hazards [of impeachment in a tribunal insufficiently dignified or independent] could only be avoided, if at all, by rendering that tribunal more numerous than would consist with a reasonable attention to economy.' " Id. (quoting The FEderalisT No. 65 at 436 (A. Hamilton) (P. Ford ed. 1888)).

173. Id. at 13 . 
holding office in the future. He might well also prevail if he were convicted without any seinblance of a trial. ${ }^{174}$

In the absence of these factors, Judge Oberdorfer simply refused to consider the constitutionality of Rule XI.

The "pohitical" political question doctrine recognizes the political nature of legislative rules of procedure, but it also recognizes the necessity of limiting the legislature's ability to affect tlirough the use of procedural rules the riglits and habilities of noulegislators. The mere presence of political motives sliould not be enough to inake a dispute nonjusticiable. After all, no one can seriously doubt that the inpeachment proceedings of Hastings and Nixon are, to soine extent, politically motivated events. ${ }^{175}$ But the political aspects of the dispute do not justify the absence of judicial review. The court should hesitate to interfere with intra-legislative disputes involving legislative rules because the rules themselves represent political tools imtended for use by legislators. The Senate creates procedural rules like Rule XI, by contrast, to protect the imterests of nonlegislators and to structure the legislative process. Nonlegislators, even allegedly corrupt federal judges, are entitled to judicial consideration of the constitutionality of these procedural provisions.

\section{CONCLUSION}

In the hands of Congress, legislative rules of procedure are not rules. They merely provide rough guidelmes for the conduct of the legislative process, quickly tossed aside when the political exigencies of the moment so demand. These rules are, no matter liow one describes them, political creatures.

An understanding of the political nature of legislative rules leads to the conclusion that courts sliould change their approach to these rules. Courts cannot justify special treatment of tliese rules by pointing to a constitutional commitment to the legislative branch, or by citing separation of powers concerns. Courts can justify special treatment, lowever, by recognizing that procedural rules are political. This conclusion requires the court to consider the identity of the plaintiff and the political realities underlymg the claim. When a legislator brings suit based upon a legislative rule, the courts usually should not interfere. When the suit is brought by a private party, the courts will generally have a proper role to play.

174. Id. at 14 .

175. Senator Joseph Lieberman pointed out that: "By its nature, impeaehment is quasi-judicial and quasi-political. I think that's the way the framers intended it to be." Legal Times, Aug. 20, 1990 , at 7 . 